\title{
Use of high and very high dose radiotherapy after radical prostatectomy for prostate cancer in the United States
}

\author{
P. Alexidis $\mathbb{D}^{1} \cdot$ W. Guo ${ }^{3} \cdot$ J. E. Bekelman ${ }^{2} \cdot$ N. Vapiwala ${ }^{2}$ P. E. Gabriel ${ }^{2} \cdot$ J. P. Christodouleas ${ }^{2}$
}

Received: 28 January 2018 / Revised: 20 March 2018 / Accepted: 27 March 2018 / Published online: 7 August 2018

(c) The Author(s) 2018. This article is published with open access

\begin{abstract}
Background The cost-benefit tradeoff of radiation dose-intensification for prostate cancer in the post-prostatectomy setting is difficult to predict and is ideally studied in randomized trials. The purpose of this study was to assess the use of doseescalated post-operative radiation (PORT) for prostate cancer in the United States, during a period in which there were no published level 1 studies on dose-escalation.

Methods We performed analyses on pT2-3, N0, M0 prostate cancer patients who received PORT after an R0-1 resection within the National Cancer Data Base (NCDB), 2003-2012. We classified patients according to the use of high dose $(>66.60 \mathrm{cGy})$ and very high dose $(>70.20 \mathrm{cGy})$ radiation. We used regression analysis to assess the association of year of treatment with use of high and very high dose PORT. To demonstrate the potential of a registry-based network like the NCDB to prospectively monitor changes in radiation dosing patterns, we determined the year in which a significant change in dose could have been first detected had dose been actively monitored.

Results Between 2003 and 2012, the use of high dose PORT increased from 29.9\% CI (26.7-33.1) to 63.5\% CI (60.6-66.5) and very high dose PORT from $4.5 \%$ CI $(3.1-5.9)$ to $10.8 \%$ CI (8.9-12.6) (adjusted $p<0.01$, for both trends). Patients diagnosed at community centers were less likely to be treated with high dose PORT compared to those at academic or comprehensive centers ( $p<0.01$ for both comparisons). Had the NCDB network been prospectively monitoring PORT dose, significant increases in dose would have been detected as early as 2004 and after every year of the study period.

Conclusions The use of both high dose and very high dose PORT increased two-fold from 2003 to 2012 in the absence of randomized studies. This change in practice may be exposing patients to excess toxicity without cancer control benefits. Monitoring dosing patterns using cancer registries is feasible.
\end{abstract}

\section{Introduction}

Incremental technical advances in linear accelerators and in image guidance have steadily improved the delivery of radiotherapy to a patient's target volume while sparing the adjacent normal tissues. However, in post-operative radiation (PORT) for prostate cancer, dose escalation cannot be achieved without increasing dose to normal tissues since

$\square$ J. P. Christodouleas

John.Christodouleas@uphs.upenn.edu

Interbalkan Center, Thessaloniki, Greece

2 Department of Radiation Oncology, University of Pennsylvania, Philadelphia, PA, USA

3 Department of Biostatistics, University of Pennsylvania, Philadelphia, PA, USA most cells within the clinical target volume are in fact part of normal/uninvolved nearby organs. As such, dose escalation in this setting invariably increases risks of toxicities. The clinical benefits of dose escalation, however, are not clear. While some retrospective studies suggest doseescalated PORT may improve biochemical control [1-6], there have been no randomized studies to support it. There does appear to be a clinical benefit from dose-intensification for intact prostate cancer, but even here the results of randomized trials have been challenging to predict [7, 8]. Moreover, randomized trials of dose-intensification in other setting, such as lung and brain cancers, have failed to validate presumed benefits [9-11].

We hypothesized that because the theoretical rationale for dose-intensification is compelling, these treatments are slowly adopted even in the absence of level 1 evidence. To test this hypothesis, that radiation dose creep occurs, we assessed the use of high dose (>66.60 cGy) and very high 
dose (>70.20 cGy) in PORT for prostate cancer in the U.S. between 2003 and 2012. In addition, we hypothesized that the U.S.'s cancer registry network as represented by the National Cancer Database (NCDB) could be used to prospectively monitor radiation dosing patterns of care and provide early signals of dose creep. To assess the potential of such a registry-based monitoring system, we determined the year in which a significant change in dose could have been first detected had dose been actively monitored.

\section{Materials/subjects and methods}

\section{Data sources}

We analyzed data extracted from the NCDB, which captures information from $\sim 70 \%$ of all newly diagnosed cancers in the United States, for the years 2003-2012. We excluded patients diagnosed prior to 2003 because those cases would have been coded prior to the publication of the Facility Oncology Registry Data Standards manual. NCDB analyses were exempted by the institutional review board (IRB).

\section{Patients}

The details of the cohort selection criteria are shown in Fig. 1. Briefly, we included men that had radical prostatectomy and PORT for prostate adenocarcinoma. To

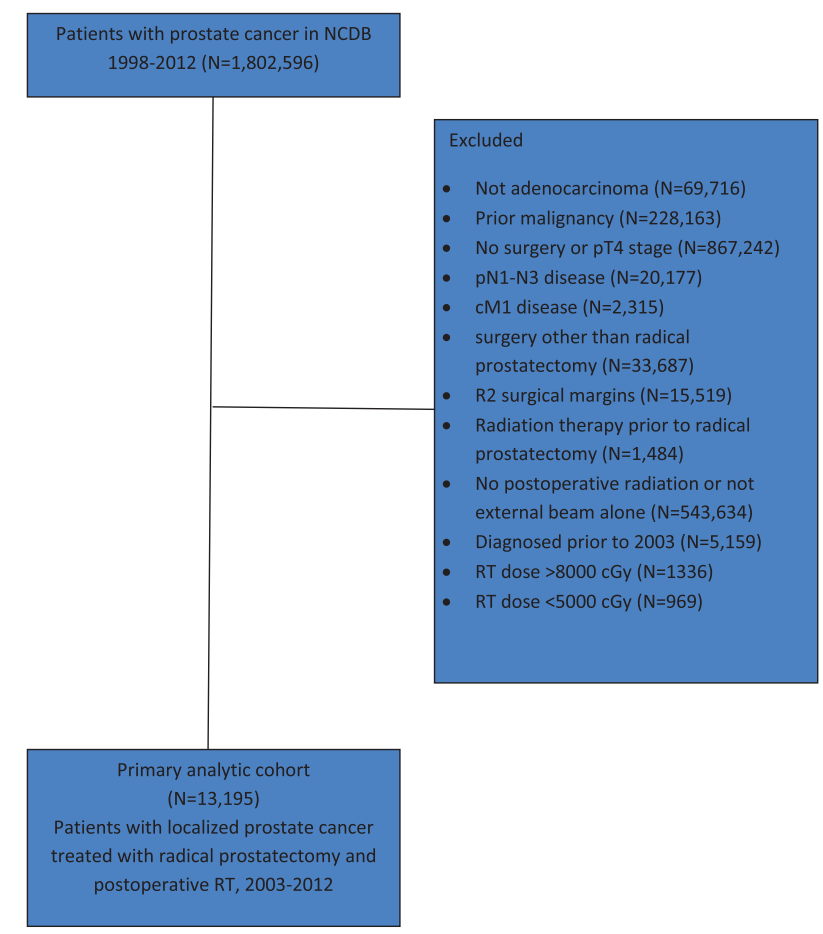

Fig. 1 The primary analytic cohort and reasons for exclusion minimize the chances of inadvertent inclusion of patients with gross residual disease after surgery (i.e. an $\mathrm{R} 2$ resection), we restricted the cohort to patients with pT2-T3 stage and no pathologically involved pelvic nodes. We excluded patients who had prior chemotherapy or RT which may affect a physician's selection of dose. In addition, we excluded patients with documented total doses of $<5000$ cGy and >8000 cGy since these are substantially outside of commonly used doses and may represent patients who discontinued treatment early or have erroneously coded values. Of note, the NCDB does not include information on a patient's post-operative pre-PORT prostate specific antigen (PSA) level, so we could not distinguish between adjuvant and salvage therapy.

\section{Primary outcomes and control variables}

We defined high dose PORT as $>6660$ cGy since 6660 cGy was the highest dose used in published randomized trials assessing adjuvant radiation [12-14]. In addition, we defined very high dose PORT as $>7020 \mathrm{cGy}$, the highest acceptable dose identified in our review of guidelines and on-going clinical trials [15-19]. We used year of diagnosis as a surrogate of year of treatment. We identified potential patient and disease covariates that might affect a physician's view of the tolerability of radiation and characteristics of the diagnosing facility that may be related to patterns of care (Table 1). Facility characteristics were defined as previously described [20, 21]. We used logistic and linear regression to assess the extent that these covariates confound the relationship of year of treatment and use of high and very high dose radiation. We calculated confidence intervals around the estimated annual percentages of patients treated with high and very high dose PORT using the Clopper-Pearson method. We used logistic regression to assess the association of year of treatment (continuous variable) with high and very high dose PORT (categorical variable) adjusting for covariates. We included potential confounders in our final adjusted model if they were associated with year of treatment or use of high or very high dose radiation on univariate analysis with a $p<0.10$ or if there was a strong clinical rationale for confounding.

We sought to demonstrate the sensitivity of a hypothetical radiation dose monitoring program within the NCDB network. To determine the year in which a significant change in dose could have been detected had dose been prospectively monitored within the NCDB, we used linear regression to compare the average annual radiation dose (continuous variable) per year with the average of the prior 3 years with adjustments for potential confounders. For 2003 and 2004, where three years of prior data were not available, we forecasted based on the prior year and two years, respectively. 
Because multiple hypotheses were being tested, we a priori set statistical significance for the primary analyses at 0.01 using Bonferroni's method.

\section{Results}

Our analytic cohort included 13,195 men (Fig. 1). Table 1 shows the distribution of patient and facility characteristics. In the NCDB cohort, the use of high dose PORT increased monotonically from $29.9 \%$ CI (26.7-33.1) in 2003 to $63.5 \%$ CI (60.6-66.5) in 2012 (Fig. 2). The use of very high dose PORT increased non-monotonically from $4.5 \%$ CI (3.1-5.9) in 2003 to $10.8 \%$ CI (8.9-12.6) in 2012 (Fig. 2). When dose was analyzed as a continuous variable, the mean value in 2003 was $6377 \mathrm{cGy}$ CI (6331-6422) and 6829 CI (6810-6846) in 2012. In our analyses of potential confounders of the use of high dose PORT, age, pathologic T stage, Gleason score, presurgical PSA, use of hormone therapy, race, Hispanic origin, Charlson-Deyo score, facility type, facility setting and insurance status were included in our final model as covariates because they were potentially associated $(p<0.10)$ with either year of treatment or use of high dose PORT (Tables 1 and 2). A similar set of covariates was included in the model of very high dose radiation, except facility setting did not meet criteria for inclusion and median income did (Tables 1 and 3). Interestingly, surgical margin status was neither associated with year of treatment nor use of high or very high dose radiation (Tables 1-3). Nonetheless, we included it as a covariate in both multivariate regressions because of the clinical rationale for dose escalating in the setting of positive margins, a common oncologic principle in other disease settings.

Year of treatment was significantly associated with use of high $(p<0.01)$ and very high $(p<0.01)$ dose PORT, even after adjusting for confounders (Tables 2 and 3). Because pre-surgical PSAs and Gleason Scores were not available in 2003 , we repeated the analysis excluding that year and found similar results.

We analyzed the effect of facility type on patterns of care. Patients diagnosed at community (and other) facilities were significantly less likely to be treated with high dose PORT compared to those diagnosed at academic or comprehensive community facilities $(p<0.01$ for both comparisons, Table 2). In contrast, patients diagnosed at academic facilities were significantly less likely to be treated with very high dose PORT compared to those diagnosed at comprehensive community facilities $(p<0.01$, Table 3$)$. Diagnosis at a comprehensive community facility was associated with the highest overall use of high and very high dose PORT.

In a proof of principle analysis, we determined the year in which our hypothetical dose monitoring system would
Table 1 The association of patient and hospital characteristics and year of treatment

\begin{tabular}{|c|c|c|}
\hline & $\begin{array}{c}\text { Analytic } \\
\text { cohort }\end{array}$ & $\begin{array}{l}p \text {-value for the association } \\
\text { with the year of treatment }\end{array}$ \\
\hline Age, mean (range) in years & $64(25-89)$ & $<0.01$ \\
\hline Pathologic stage, No (\%) & & $<0.01$ \\
\hline $\mathrm{T} 2$ & $3614(27.4)$ & \\
\hline $\mathrm{T} 3$ & $9581(72.6)$ & \\
\hline Gleason score, No (\%) & & $<0.01$ \\
\hline$\leq 6$ & $1283(9.7)$ & \\
\hline 7 & $6354(48.1)$ & \\
\hline $8-10$ & 4435 (33.6) & \\
\hline Missing & $1123(8.5)$ & \\
\hline Pre surgical PSA, No (\%) & & $<0.01$ \\
\hline$<10 \mathrm{ng} / \mathrm{ml}$ & $7901(59.9)$ & \\
\hline $10-20 \mathrm{ng} / \mathrm{ml}$ & $2235(16.9)$ & \\
\hline$>20 \mathrm{ng} / \mathrm{ml}$ & $1512(11.5)$ & \\
\hline Missing & $1547(11.7)$ & \\
\hline Surgical margins, No (\%) & & 0.44 \\
\hline Positive & $8817(66.8)$ & \\
\hline Negative & $4378(33.2)$ & \\
\hline Hormone therapy, No (\%) & & $<0.01$ \\
\hline Yes & $3878(29.4)$ & \\
\hline No & $8968(68.0)$ & \\
\hline Unknown & $349(2.6)$ & \\
\hline Race, No (\%) & & 0.01 \\
\hline White & $10819(82.0)$ & \\
\hline Black & 1766 (13.4) & \\
\hline Other & $610(4.6)$ & \\
\hline Hispanic origin, No (\%) & & $<0.01$ \\
\hline Spanish & $579(4.4)$ & \\
\hline Non-Spanish & $11399(86.4)$ & \\
\hline Unknown & $1217(9.2)$ & \\
\hline Facility location, No (\%) & & 0.35 \\
\hline East & $5017(38.0)$ & \\
\hline West & $2579(19.5)$ & \\
\hline Central north & $4051(30.8)$ & \\
\hline Central south & $1548(11.7)$ & \\
\hline Charlson-Deyo score, No (\%) & & $<0.01$ \\
\hline 0 & $11158(84.6)$ & \\
\hline 1 & $1805(13.7)$ & \\
\hline $2+$ & $232(1.8)$ & \\
\hline Facility type, No (\%) & & $<0.01$ \\
\hline Community and other & $1456(11.0)$ & \\
\hline Comprehensive & $7537(57.2)$ & \\
\hline Academic & $4202(31.8)$ & \\
\hline Hospital setting, No (\%) & & 0.77 \\
\hline Metro & $10778(81.7)$ & \\
\hline Non-metro & $2036(15.4)$ & \\
\hline Missing & $381(2.9)$ & \\
\hline Median income, No (\%) & & 0.66 \\
\hline$<38,000$ & $1863(14.1)$ & \\
\hline $38,000-47,999$ & $2821(21.4)$ & \\
\hline $48,000-62,999$ & $3671(27.8)$ & \\
\hline$>63,000$ & $4664(35.3)$ & \\
\hline Missing & $176(1.3)$ & \\
\hline Insurance status, No (\%) & & $<0.01$ \\
\hline No insurance & $240(1.8)$ & \\
\hline
\end{tabular}


Table 1 (continued)

\begin{tabular}{lll}
\hline & $\begin{array}{l}\text { Analytic } \\
\text { cohort }\end{array}$ & $\begin{array}{l}p \text {-value for the association } \\
\text { with the year of treatment }\end{array}$ \\
\hline Private & $8432(63.9)$ \\
Medicaid & $338(2.6)$ \\
Medicare & $3755(28.5)$ \\
Other & $238(1.8)$ \\
Unknown & $192(1.5)$ \\
\hline
\end{tabular}

PSA prostate specific antigen

${ }^{\mathrm{a}} \mathrm{Chi}$ square test for categorical and $t$ test for continuous variables

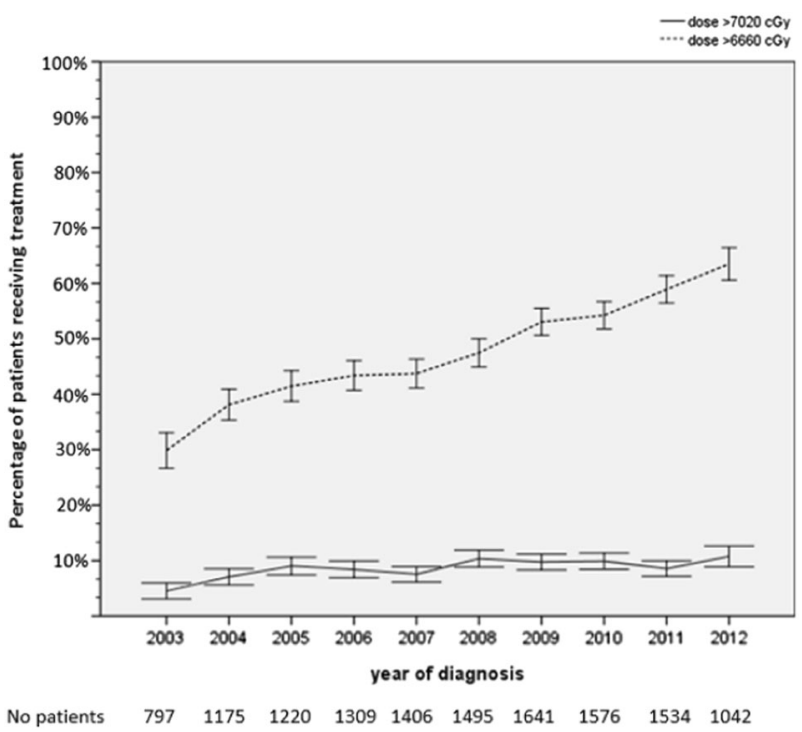

Fig. 2 Use of high and very high dose post-operative radiation after radical prostatectomy for prostate cancer, 2003-2012. Bars represent $95 \%$ confidence intervals

have detected a significant change in this cohort. Using an adjusted 3-year rolling average, we found that a significant increase in average dose would have been first detected in 2004 and that a significant change would have been detected after every year in the study period had the NCDB been prospectively monitoring dose in this cohort (Fig. 3).

\section{Discussion}

We found that the use of high and very high dose PORT for prostate cancer increased in the U.S. between 2003 and 2012. By 2012, $\sim 2$ out of 3 post-prostatectomy patients were treated with doses $>6660 \mathrm{cGy}$ and 1 out of 9 were treated with doses $>7020 \mathrm{cGy}$. This observation is consistent with our hypothesis that radiation dose creep occurred in the absence of level I evidence.

There is retrospective evidence in support of dose escalated PORT > $6660 \mathrm{cGy}$, particularly in the salvage setting. Ohri et al. [22] performed a meta-analysis with radiobiologic modeling using data from 25 retrospective series of salvage PORT with median PORT doses that ranged from 60 to $72 \mathrm{~Gy}$. They found that salvage PORT dose was an independent predictor of 5-year bPFS and estimated that this endpoint improves $2.5 \%$ per additional $100 \mathrm{cGy}$. In a prior modeling study, King and Kapp [1] found that the tumor control probability dose-response curves for intact prostate cancer and salvage PORT were similar. The dose to achieve $50 \%$ biochemical tumor control was $6590 \mathrm{cGy}$ versus $6680 \mathrm{cGy}$ for intact prostate radiation and salvage PORT respectively. Of note, the estimated dose to achieve $50 \%$ biochemical tumor control was approximately $600 \mathrm{cGy}$ less for patients treated in the adjuvant PORT setting. The retrospective data to support doses $>$ 7020 cGy is substantially more limited. Cozzarini et al. [3] retrospectively compared outcomes of salvage PORT patients treated with $<7020 \mathrm{cGy}$ vs. $\geq 7020 \mathrm{cGy}$. Five-year biochemical progression free survival favored the high dose group (83 vs. $71 \%$ ). In contrast, Goenka et al. [23], found that a salvage PORT dose $>70$ Gy was not associated with improved biochemical control in patients without evidence of gross residual disease after surgery. To our knowledge, there is presently no randomized evidence supporting dose escalation. SAKK $09 / 10$ is a randomized trial comparing 6400 cGy versus 7000 cGy of salvage PORT [24]. It completed accrual in 2014, but cancer control outcomes have not yet been reported.

The generally favorable results of the retrospective studies of dose escalated PORT could also be explained by confounding. As observed in our NCDB analysis, increasing year of treatment is likely also associated with PORT dose in these retrospective series because dose creep occurs slowly over time. As such, the outcomes of these studies may suffer from stage migration. Improvements in pre- and post-operative imaging over time may better detect patients with gross residual disease after surgery, involved pelvic nodes or distant metastases, which, without any change in treatment, would result in an apparent improvement in cancer control outcomes for PORT patients classified as R01, N0, M0. In addition, the retrospective literature may suffer from ascertainment bias since there is a greater opportunity to document a failure event in patients with longer follow-up. Patients treated at higher doses may also have been favorably selected since physicians may be more likely to use novel approaches in the healthiest candidates. Another major weakness of the existing retrospective literature is the use of a biochemical control endpoint. In a disease that is diagnosed in older men and that typically has a long natural history, biochemical control may not be valid surrogate of more clinically meaningful endpoints, which to our knowledge, have not been extensively studied.

There is also evidence that escalating PORT doses are associated with worse toxicity outcomes. The rationale for 
Table 2 The univariate and multivariate association of year of treatment and use of high dose (>6660 cGy) post-operative radiation in the treatment of prostate cancer

\begin{tabular}{|c|c|c|c|c|c|c|}
\hline & \multirow[t]{2}{*}{$<6660 \mathrm{cGy}$} & \multirow[t]{2}{*}{$>6660$ cGy } & \multicolumn{2}{|l|}{ Univariate } & \multicolumn{2}{|l|}{ Multivariate } \\
\hline & & & $\mathrm{OR}(\mathrm{CI})$ & $p$-value ${ }^{\mathrm{a}}$ & $\mathrm{OR}(\mathrm{CI})$ & $p$-value ${ }^{\mathrm{a}}$ \\
\hline Year of treatment & & & $\begin{array}{l}1.14 \\
(1.12-1.15)\end{array}$ & $<0.01$ & $\begin{array}{l}1.14 \\
(1.12-1.16)\end{array}$ & $<0.01$ \\
\hline Age, mean (range) & $60.6(37-89)$ & $60.6(25-87)$ & $\begin{array}{l}1.00 \\
(1.00-1.01)\end{array}$ & 0.79 & $\begin{array}{l}0.99 \\
(0.98-1.00)\end{array}$ & 0.06 \\
\hline Pathologic T stage, No (\%) & & & $\begin{array}{l}1.01 \\
(0.90-1.09)\end{array}$ & 0.70 & $\begin{array}{l}0.90 \\
(0.80-1.00)\end{array}$ & 0.07 \\
\hline $\mathrm{T} 2$ & $1877(27.5)$ & $1737(27.2)$ & & & & \\
\hline $\mathrm{T} 3$ & $4941(72.5)$ & $4640(72.8)$ & & & & \\
\hline Gleason score, No (\%) & & & $\begin{array}{l}0.92 \\
(0.90-0.96)\end{array}$ & 0.01 & $\begin{array}{l}0.98 \\
(0.93-1.00)\end{array}$ & 0.50 \\
\hline$\leq 6$ & $666(9.8)$ & $617(9.7)$ & & & & \\
\hline 7 & $3263(47.9)$ & $3091(48.5)$ & & & & \\
\hline $8-10$ & $2168(31.8)$ & $2267(35.5)$ & & & & \\
\hline Missing & $721(10.6)$ & $402(6.3)$ & & & & \\
\hline Pre-surgical PSA, No (\%) & & & $\begin{array}{l}0.94 \\
(0.91-0.97)\end{array}$ & $<0.01$ & $\begin{array}{l}1.03 \\
(1.00-1.06)\end{array}$ & 0.13 \\
\hline$<10 \mathrm{ng} / \mathrm{ml}$ & $4064(59.6)$ & $3837(60.2)$ & & & & \\
\hline $10-20 \mathrm{ng} / \mathrm{ml}$ & $1092(16)$ & $1143(17.9)$ & & & & \\
\hline$>20 \mathrm{ng} / \mathrm{ml}$ & $746(10.9)$ & $766(12)$ & & & & \\
\hline Missing & $916(13.4)$ & $631(9.9)$ & & & & \\
\hline Surgical margins, No (\%) & & & $\begin{array}{l}0.97 \\
(0.90-1.00)\end{array}$ & 0.37 & $\begin{array}{l}0.95 \\
(0.80-1.00)\end{array}$ & 0.20 \\
\hline Positive & $4580(67.2)$ & $4237(66.4)$ & & & & \\
\hline Negative & $2238(32.8)$ & $2140(33.6)$ & & & & \\
\hline Hormone therapy, No (\%) & & & $\begin{array}{l}1.09 \\
(1.02-1.20)\end{array}$ & 0.01 & $\begin{array}{l}1.10 \\
(1.07-1.20)\end{array}$ & $<0.01$ \\
\hline Yes & $1944(28.5)$ & $1934(30.3)$ & & & & \\
\hline No & $4703(69.0)$ & $4265(66.9)$ & & & & \\
\hline Unknown & $171(2.5)$ & $178(2.8)$ & & & & \\
\hline Race, No (\%) & & & $\begin{array}{l}0.97 \\
(0.90-1.00)\end{array}$ & 0.29 & $\begin{array}{l}0.91 \\
(0.86-0.92)\end{array}$ & 0.01 \\
\hline White & $5572(81.7)$ & $5247(82.3)$ & & & & \\
\hline Black & $918(13.5)$ & $848(13.3)$ & & & & \\
\hline Other & $328(4.8)$ & $282(4.4)$ & & & & \\
\hline Hispanic origin, No (\%) & & & $\begin{array}{l}0.95 \\
(0.89-1.00)\end{array}$ & 0.05 & $\begin{array}{l}0.98 \\
(0.93-1.00)\end{array}$ & \\
\hline Spanish & $328(4.8)$ & $251(3.9)$ & & & & \\
\hline Non-Spanish & $5843(85.7)$ & $5556(87.1)$ & & & & \\
\hline Unknown & $647(9.5)$ & $570(8.9)$ & & & & \\
\hline $\begin{array}{l}\text { Charlson-Deyo score, No } \\
(\%)\end{array}$ & & & $\begin{array}{l}1.00 \\
(0.93-1.09)\end{array}$ & 0.79 & $\begin{array}{l}0.97 \\
(0.89-1.05)\end{array}$ & 0.53 \\
\hline 0 & $5777(84.7)$ & $5381(84.4)$ & & & & \\
\hline 1 & $916(13.4)$ & 889 (13.9) & & & & \\
\hline $2+$ & $125(1.8)$ & $107(1.7)$ & & & & \\
\hline Facility type, No (\%) & & & $\begin{array}{l}1.15 \\
(1.09-1.21)\end{array}$ & $<0.01$ & $\begin{array}{l}1.11 \\
(1.05-1.18)\end{array}$ & $<0.01$ \\
\hline Community+other & $873(12.8)$ & $583(9.1)$ & & & & \\
\hline Comprehensive & $3832(56.2)$ & $3705(58.1)$ & & & & \\
\hline
\end{tabular}


Table 2 (continued)

\begin{tabular}{|c|c|c|c|c|c|c|}
\hline & \multirow[t]{2}{*}{$<6660$ cGy } & \multirow[t]{2}{*}{$>6660$ cGy } & \multicolumn{2}{|l|}{ Univariate } & \multicolumn{2}{|l|}{ Multivariate } \\
\hline & & & $\mathrm{OR}(\mathrm{CI})$ & $p$-value ${ }^{\mathrm{a}}$ & $\mathrm{OR}(\mathrm{CI})$ & $p$-value ${ }^{\mathrm{a}}$ \\
\hline Academic & $2113(31.0)$ & 2089 (32.8) & & & & \\
\hline Hospital setting & & & $\begin{array}{l}0.88 \\
(0.80-0.97)\end{array}$ & 0.01 & $\begin{array}{l}0.90 \\
(0.82-1.00)\end{array}$ & 0.05 \\
\hline Metro & $5502(80.7)$ & $5276(82.7)$ & & & & \\
\hline Non-metro & $1100(16.1)$ & 936 (14.7) & & & & \\
\hline Missing & $216(3.2)$ & $165(2.6)$ & & & & \\
\hline Facility location & & & $\begin{array}{l}0.99 \\
(0.96-1.02)\end{array}$ & 0.86 & & \\
\hline East & 2563 (37.6) & 2454 (38.6) & & & & \\
\hline West & $1377(20.2)$ & $1202(18.8)$ & & & & \\
\hline Central north & $2185(32.0)$ & $1866(29.3)$ & & & & \\
\hline Central south & $693(10.2)$ & 855 (13.4) & & & & \\
\hline Insurance status & & & $\begin{array}{l}1.01 \\
(0.98-1.03)\end{array}$ & 0.39 & $\begin{array}{l}1.02 \\
(0.99-1.05)\end{array}$ & 0.12 \\
\hline No insurance & 129 (1.9) & $111(1.7)$ & & & & \\
\hline Private & $4381(64.3)$ & 4051 (63.5) & & & & \\
\hline Medicaid & $185(2.7)$ & $153(2.4)$ & & & & \\
\hline Medicare & $1911(28.0)$ & 1844 (28.9) & & & & \\
\hline Other & 109 (1.6) & $129(2.0)$ & & & & \\
\hline Unknown & $103(1.5)$ & 89 (1.4) & & & & \\
\hline Median income & & & $\begin{array}{l}1.00 \\
(0.97-1.04)\end{array}$ & 0.65 & & . \\
\hline$<38,000$ & $992(14.8)$ & $871(13.8)$ & & & & \\
\hline $38,000-47,999$ & $1418(21.1)$ & 1403 (22.3) & & & & \\
\hline $48,000-62,999$ & 1909 (28.4) & $1762(28.0)$ & & & & \\
\hline$>63,000$ & $2403(35.7)$ & $2261(35.9)$ & & & & \\
\hline
\end{tabular}

$P S A$ prostate specific antigen, $O R$ odds ratio, $C I$ confidence interval

${ }^{a}$ Chi square test for categorical and $t$ test for continuous variables

such a relationship is strong since PORT clinical target volume includes at-risk normal tissue. In 2015, Ghadjar et al. reported the initial acute toxicity results of the SAKK 09/10 randomized trial. Patients in the high dose salvage PORT arm reported a more pronounced and clinically relevant worsening in acute urinary symptoms, though differences in clinician- reported acute genitourinary (GU) and gastrointestinal (GI) toxicities were not significantly different. In a meta-analysis of 25 retrospective series of salvage PORT by Ohri et al., estimates of late grade $3+\mathrm{GU}$ and GI toxicity ranged from $1-11 \%$ to $0-9 \%$, respectively. PORT dose was an independent predictor of both late grade $3+\mathrm{GU}$ and GI toxicity. Estimated risk increased at a rate of 0.8 and $1.2 \%$ per $100 \mathrm{cGy}$ for GU and GI late grade $3+$ toxicity. It should be noted that of the 13 studies included in this meta-analyses of toxicities, nine had four or fewer years of toxicity follow up. The long-term toxicity experience of PORT patients is largely unknown.
The data dictionary (FORDS Manual) for NCDB field that codes radiation modality (i.e., intensity modulated radiation therapy (IMRT), 3D conformal, etc.) has inconsistencies that make it unreliable. In particular, it allows registrars to select from options that are not mutually exclusive (e.g., IMRT versus Photons (6-10MV)). As such, we did not include modality as a variable in our analysis. Nonetheless, we suspect that the increasing availability of IMRT in the study period was an important driver of the increasing use of high and very high dose PORT. A recent analysis that used Medicare claims data to ascertain IMRT utilization rates in the United States found that the use of IMRT in the post-operative treatment of prostate cancer increased from zero to $82 \%$ between the years 2000 and 2009 [25]. This increase in IMRT utilization parallels the PORT dose trends observed in our study.

In short, the existing retrospective literature may be misleading and the results of randomized comparisons like 
Table 3 The univariate and multivariate association of year of treatment and use of very high dose ( $>7020$ cGy) post-operative radiation in the treatment of prostate cancer

\begin{tabular}{|c|c|c|c|c|c|c|}
\hline & \multirow[t]{2}{*}{$<7020$ cGy } & \multirow[t]{2}{*}{$>7020$ cGy } & \multicolumn{2}{|l|}{ Univariate } & \multicolumn{2}{|l|}{ Multivariate } \\
\hline & & & $\mathrm{OR}(\mathrm{CI})$ & $p$-value* & $\mathrm{OR}(\mathrm{CI})$ & $p$-value ${ }^{\mathrm{a}}$ \\
\hline Year of treatment & & & $\begin{array}{l}1.05 \\
(1.03-1.07)\end{array}$ & $<0.01$ & $\begin{array}{l}1.05 \\
(1.03-1.08)\end{array}$ & $<0.01$ \\
\hline Age, mean (range) & $60.6(25-89)$ & $60.6(38-85)$ & $\begin{array}{l}1.01 \\
(1.00-1.02)\end{array}$ & 0.06 & $\begin{array}{l}1.01 \\
(1.00-1.02)\end{array}$ & 0.05 \\
\hline Pathologic stage, No (\%) & & & $\begin{array}{l}0.86 \\
(0.76-0.99)\end{array}$ & 0.03 & $\begin{array}{l}0.82 \\
(0.72-0.95)\end{array}$ & $<0.01$ \\
\hline $\mathrm{T} 2$ & $3266(27.1)$ & $348(30.0)$ & & & & \\
\hline $\mathrm{T} 3$ & $8770(72.9)$ & $811(70.0)$ & & & & \\
\hline Gleason score, No (\%) & & & $\begin{array}{l}0.93 \\
(0.86-1.00)\end{array}$ & $<0.01$ & $\begin{array}{l}0.94 \\
(0.86-1.00)\end{array}$ & 0.19 \\
\hline$\leq 6$ & $1165(9.7)$ & $118(10.2)$ & & & & \\
\hline 7 & $5793(48.1)$ & $561(48.4)$ & & & & \\
\hline $8-10$ & $4021(33.4)$ & 414 (35.7) & & & & \\
\hline Missing & $1057(8.8)$ & $66(5.7)$ & & & & \\
\hline Pre-surgical PSA, No (\%) & & & $\begin{array}{l}0.96 \\
(0.90-1.00)\end{array}$ & 0.01 & $\begin{array}{l}1.00 \\
(0.94-1.06)\end{array}$ & 0.93 \\
\hline$<10 \mathrm{ng} / \mathrm{ml}$ & $7190(59.7)$ & $711(61.3)$ & & & & \\
\hline $10-20 \mathrm{ng} / \mathrm{ml}$ & $2053(17.1)$ & $182(15.7)$ & & & & \\
\hline$>20 \mathrm{ng} / \mathrm{ml}$ & $1358(11.3)$ & $154(13.3)$ & & & & \\
\hline Missing & 1435 (11.9) & $112(9.7)$ & & & & \\
\hline Surgical margins, No (\%) & & & $\begin{array}{l}0.95 \\
(0.83-1.08)\end{array}$ & 0.45 & $\begin{array}{l}0.94 \\
(0.82-1.07)\end{array}$ & 0.41 \\
\hline Positive & $8054(66.9)$ & $763(65.8)$ & & & & \\
\hline Negative & $3982(33.1)$ & $396(34.2)$ & & & & \\
\hline Hormone therapy, No (\%) & & & $\begin{array}{l}1.13 \\
(1.01-1.26)\end{array}$ & 0.03 & $\begin{array}{l}1.19 \\
(1.06-1.33)\end{array}$ & $<0.01$ \\
\hline Yes & $3498(29.1)$ & $380(32.8)$ & & & & \\
\hline No & $8219(68.3)$ & 749 (64.6) & & & & \\
\hline Unknown & $319(2.7)$ & $30(2.6)$ & & & & \\
\hline Race, No (\%) & & & $\begin{array}{l}0.96 \\
(0.85-1.08)\end{array}$ & 0.42 & $\begin{array}{l}0.97 \\
(0.86-1.10)\end{array}$ & 0.50 \\
\hline White & $9857(81.9)$ & $962(83.0)$ & & & & \\
\hline Black & $1625(13.5)$ & $141(12.2)$ & & & & \\
\hline Other & $554(4.6)$ & $56(4.8)$ & & & & \\
\hline Hispanic origin, No (\%) & & & $\begin{array}{l}1.06 \\
(0.96-1.16)\end{array}$ & 0.49 & $\begin{array}{l}1.07 \\
(0.97-1.18)\end{array}$ & 0.11 \\
\hline Spanish & $525(4.4)$ & $54(4.7)$ & & & & \\
\hline Non-Spanish & $10411(86.5)$ & $988(85.2)$ & & & & \\
\hline Unknown & $1100(9.1)$ & $117(10.1)$ & & & & \\
\hline Charlson-Deyo score, No (\%) & & & $\begin{array}{l}1.03 \\
(0.89-1.18)\end{array}$ & 0.01 & $\begin{array}{l}1.00 \\
(0.87-1.15)\end{array}$ & 0.92 \\
\hline 0 & $10192(84.7)$ & $966(83.3)$ & & & & \\
\hline 1 & $1624(13.5)$ & $181(15.6)$ & & & & \\
\hline $2+$ & $220(1.8)$ & $12(1.0)$ & & & & \\
\hline Facility type, No (\%) & & & $\begin{array}{l}0.90 \\
(0.82-0.99)\end{array}$ & $<0.01$ & $\begin{array}{l}0.90 \\
(0.82-1.00)\end{array}$ & 0.05 \\
\hline Community and other & $1342(11.1)$ & $114(9.8)$ & & & & \\
\hline Comprehensive & $6807(56.6)$ & $730(63.0)$ & & & & \\
\hline
\end{tabular}


Table 3 (continued)

\begin{tabular}{|c|c|c|c|c|c|c|}
\hline & \multirow[t]{2}{*}{$<7020$ cGy } & \multirow[t]{2}{*}{$>7020$ cGy } & \multicolumn{2}{|l|}{ Univariate } & \multicolumn{2}{|l|}{ Multivariate } \\
\hline & & & $\mathrm{OR}(\mathrm{CI})$ & $p$-value* & $\mathrm{OR}(\mathrm{CI})$ & $p$-value ${ }^{a}$ \\
\hline Academic & $3887(32.3)$ & $315(27.2)$ & & & & \\
\hline Hospital setting, No (\%) & & & $\begin{array}{l}0.96 \\
(0.81-1.14)\end{array}$ & 0.69 & & . \\
\hline Metro & $9828(81.6)$ & $950(82.0)$ & & & & \\
\hline Non-metro & $1862(15.5)$ & $174(15.0)$ & & & & \\
\hline Missing & $346(2.9)$ & $35(3.0)$ & & & & \\
\hline Facility location, No (\%) & & & $\begin{array}{l}1.03 \\
(0.97-1.01)\end{array}$ & 0.25 & & \\
\hline East & $4587(38.1)$ & $430(37.1)$ & & & & \\
\hline West & $2339(19.4)$ & $240(20.7)$ & & & & \\
\hline Central north & $3702(30.8)$ & $349(30.1)$ & & & & \\
\hline Central south & $1408(11.7)$ & $140(12.1)$ & & & & \\
\hline Insurance status, No (\%) & & & $\begin{array}{l}0.99 \\
(0.95-1.04)\end{array}$ & 0.46 & $\begin{array}{l}0.97 \\
(0.92-1.03)\end{array}$ & 0.34 \\
\hline No insurance & $220(1.8)$ & $20(1.7)$ & & & & \\
\hline Private & $7699(64)$ & $733(63.2)$ & & & & \\
\hline Medicaid & $310(2.6)$ & $28(2.4)$ & & & & \\
\hline Medicare & $3405(28.3)$ & $350(30.2)$ & & & & \\
\hline Other & $223(1.9)$ & $15(1.3)$ & & & & \\
\hline Unknown & $179(1.5)$ & $13(1.1)$ & & & & \\
\hline Median income, No (\%) & & & $\begin{array}{l}0.94 \\
(0.88-0.99)\end{array}$ & 0.05 & $\begin{array}{l}0.93 \\
(0.88-0.99)\end{array}$ & 0.03 \\
\hline$<38,000$ & $1690(14.2)$ & $173(15.1)$ & & & & \\
\hline $38,000-47,999$ & $2542(21.4)$ & $279(24.4)$ & & & & \\
\hline $48,000-62,999$ & $3364(28.3)$ & 307 (26.9) & & & & \\
\hline$>63,000$ & $4281(36)$ & $383(33.5)$ & & & & \\
\hline
\end{tabular}

PSA prostate specific antigen

${ }^{\mathrm{a}} \mathrm{Chi}$ square test for categorical and t test for continuous variables

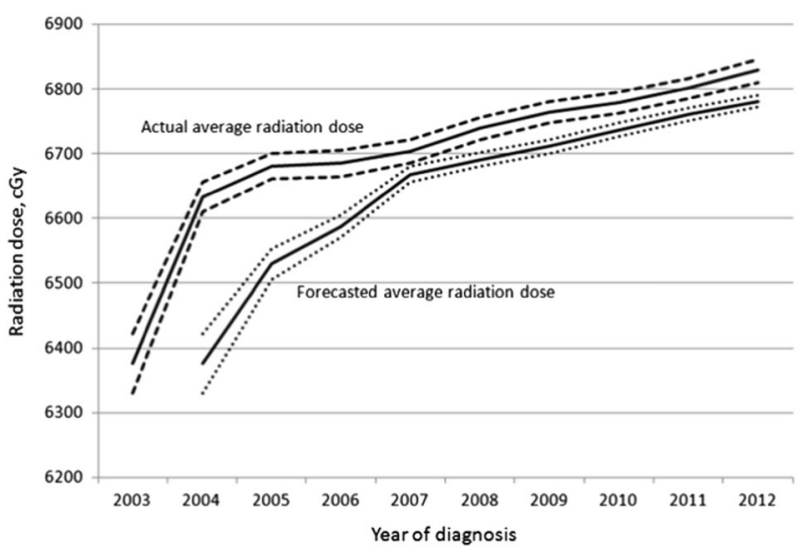

Fig. 3 Actual average radiation dose over time versus the forecasted averaged radiation dose (long dashed line). The forecasted averaged radiation dose for a given year was calculated based on the previous three years, except for 2004 and 2005 where it was based on the previous one and two years, respectively. The dashed lines represent 95\% confidence intervals
SAKK 09/10 may be surprising. Something akin to this may have occurred in the radical treatment of locally advanced non-small cell lung cancer. In that disease, the retrospective evidence overwhelmingly favored dose escalation and dose creep was observed in the U.S between 2003 and 2010 [26]. Yet, when the first randomized comparison was reported in 2011, it demonstrated a substantial worsening of toxicity and overall survival in the dose-escalation arm [27].

Another goal of this study was to assess the potential of a prospective national cancer registry-based monitoring system to detect dosing patterns of care and provide early signals of dose creep. In a proof-of-principal analysis, we found that an increasing mean dose of radiation for this cohort could have been detected within the Commission on Cancer's (CoC) NCDB network as early as 2004 and that a significant change would have been detected after every year in the study period. As such, a national infrastructure for monitoring radiation dosing patterns of care in this 
cohort and others already exists. Many centers in the U.S. now participate in the CoC's credentialing program and are already extracting data on radiation dose. The CoC, SEER and other programs that aggregate cancer registry data could feasibly monitor dose to identify cohorts for which the patterns of care are changing in the absence of high level evidence.

This study has important limitations. The NCDB only captures cases where PORT was used as part of the first course of therapy [28]. Patients treated with PORT due to late post-operative biochemical recurrences may have different patterns of care. In addition, we cannot distinguish between patients receiving adjuvant versus salvage therapy as part of the first course of therapy. If these patients are treated differently and their relative proportions are changing over time, changes in dosing may be obscured or magnified. We are also unable to identify patients treated on a clinical trial. It may be that the dose trends we identified are in part reflective of increasing research interests in doseescalation. Finally, though the NCDB captures $70 \%$ of U.S. cancer cases, patients from small and rural facilities may be under represented.

Funding This work was funded using institutional support from the University of Pennsylvania.

\section{Compliance with ethical standards}

Conflict of interest JPC reports part-time employment at Elekta, AB, and has served as a consultant to the Commission on Cancer. The remaining authors declare that they have no conflict of interest.

Open Access This article is licensed under a Creative Commons Attribution 4.0 International License, which permits use, sharing, adaptation, distribution and reproduction in any medium or format, as long as you give appropriate credit to the original author(s) and the source, provide a link to the Creative Commons license, and indicate if changes were made. The images or other third party material in this article are included in the article's Creative Commons license, unless indicated otherwise in a credit line to the material. If material is not included in the article's Creative Commons license and your intended use is not permitted by statutory regulation or exceeds the permitted use, you will need to obtain permission directly from the copyright holder. To view a copy of this license, visit http://creativecommons. org/licenses/by/4.0/.

\section{References}

1. King CR, Kapp DC. Radiotherapy after prostatectomy: is the evidence for dose escalation out there? Int J Radiat Oncol Biol Phys. 2008;71:346-50.

2. King CR, Spiotto MT. Improved outcomes with higher doses for salvage radiotherapy after prostatectomy. Int J Radiat Oncol Biol Phys. 2008;71:23-27.

3. Cozzarini C, Montorsi F, Fiorino C, Alongi F, Bolognesi A, Da Pozzo LF, et al. Need for high radiation dose ( $>70 \mathrm{~Gy}$ ) in early postoperative irradiation after radical prostatectomy: a single institution analysis of 334 high risk node negative patients. Int $\mathrm{J}$ Radiat Oncol Biol Phys. 2009;75:966-74.

4. Ost P, Cozzarini C, De Meerleer G, Fiorino C, De Potter B, Briganti $\mathrm{A}$, et al. High-dose adjuvant radiotherapy after radical prostatectomy with or without androgen deprivation therapy. Int J Radiat Oncol Biol Phys. 2011;83:960-5.

5. Siegmann A, Bottke D, Faendrich J, Lohm G, Miller K, Bartkowiak D, et al. Dose escalation for patients with decreasing PSA during radiotherapy for elevated PSA after radical prostatectomy improves biochemical progression-free survival. Results of a retrospective study. Strahlenther Onkol. 2011;187:467-72.

6. Alongi F, Fiorino C, Cozzarini C, Broggi S, Perna L, Cattaneo GM, et al. IMRT significantly reduces acute toxicity of wholepelvis irradiation in patients treated with post-operative adjuvant or salvage radiotherapy after radical prostatectomy. Radiother Oncolo. 2009;93:207-12.

7. Aluwini S, Pos F, Schimmel E, van Lin E, Krol S, van der Toorn $\mathrm{PP}$, et al. Hypofractionated versus conventionally fractionated radiotherapy for patients with prostate cancer (HYPRO): acute toxicity results from a randomized non inferiority phase 3 trial. Lancet Oncol. 2015;16:274-83.

8. Morris WJ, Tyldesley S, Rodda S, Halperin R, Pai H, McKenzie $\mathrm{M}$, et al. Androgen suppression combined with elective nodal and dose escalated radiation therapy (the ASCENDE-RT Trial): an analysis of survival endpoints for a randomized trial comparing a low-dose-rate brachytherapy boost to a dose-escalated external beam boost for high- and intermediate-risk prostate cancer. Int $\mathbf{J}$ Radiat Oncol Biol Phys. 2017;98:275-85.

9. Curran WJ Jr, Paulus R, Langer CJ, Komaki R, Lee JS, Hauser S, et al. Sequential vs concurrent chemoradiaton for stage III nonsmall cell lung cancer: randomized phase III trial RTOG 9401. J Natl Cancer Inst. 2011;103:1452-60.

10. Chan JL, Lee SW, Fraass BA, Normolle DP, Greenberg HS, Junck LR, et al. Survival and failure patterns of high grade gliomas after three-dimensional conformal radiotherapy. J Clin Oncol. 2002;20:1635-42.

11. Bradley JD, Paulus R, Komaki R, Masters G, Blumenschein G, Schild S, et al. Standard dose versus high dose conformal radiotherapy with concurrent and consolidation carboplatin plus paclitaxel with or without cetuximab for patients with stage IIIA or IIIB non-small cell lung cancer (RTOG 0617): a randomized, two by two factorial phase 3 study. Lancet Oncol. 2015;16:187-99.

12. Swanson GP, Hussey MA, Tangen CM, Chin J, Messing E, Canby-Hagino E, et al. Predominant treatment failure in postprostatectomy patients is local: analysis of patterns of treatment failure in SWOG 8794. J Clin Oncol. 2007;25:2225-9.

13. Wiegel T, Bartkowiak D, Bottke D, Bronner C, Steiner U, Siegmann A, et al. Adjuvant radiotherapy versus wait and see after radical prostatectomy: 10 year follow-up of the ARO 96-02/AUO AP 09/95 trial. Eur Urol. 2014;66:243-50.

14. Van der Kwast TH, Bolla M, Van Poppel H, Van Cangh P, Vekemans K, Da Pozzo L, et al. Identification or patients with prostate cancer who benefit from immediate postoperative radiotherapy: EORTC 22911. J Clin Oncol. 2007;25:4178-86.

15. Gustafson GS, Nguyen PL, Assimos DG, D’Amico AV, Gottschalk AR, et al. ACR appropriateness criteria postradcial prostatectomy irradiation in prostate cancer. https://acsearch.acr.org/ docs/69400/Narrative/

16. Adjuvant Radiotherapy Following Radical Prostatectomy for Pathologic T3 or Margin-Positive Prostate cancer http://www.ca ncercare.on.ca.

17. Prostate Cancer: Diagnosis and Treatment. NICE Clinical Guidelines 175 Guidance.nice.org.uk/cg175.

18. Valicenti RK, Thompson I Jr, Albertsen P, Davis BJ, Goldenberg 
SL, Wolf JS, et al. Adjuvant and salvage radiation therapy after prostatectomy: American Society of Radiation Oncology/American Urological Association Guidelines. Int J Radiat Oncol Biol Phys. 2013;86:822-8.

19. NCCN Clinical Practice Guidelines in Oncology, Prostate cancer. www.ncen.org/patients.

20. CoC AccreditationCategories. https://www.facs.org/qualityprogra $\mathrm{ms} /$ cancer/accredited/about/categories

21. RuralUrbanContinuumCodes. https://seer.cancer.gov/seerstat/va riables/countyattribs/ruralurban.html

22. Ohri N, Dicker AP, Trabulsi EJ, Showalter TN. Can early implementation of salvage radiotherapy for prostate cancer improve the therapeutic ratio? A systematic review and regression meta-analysis with radiobiological modelling. Eur $\mathrm{J}$ Cancer. 2012;48:837-44.

23. Goenka A, Magsanoc JM, Pei X, Schechter M, Kollmeier M, Cox $\mathrm{B}$, et al. Improved toxicity profile following high-dose post prostatectomy salvage radiation therapy with intensity-modulated radiation therapy. Eur Urol. 2011;60:1142-8.

24. Ghadjar P, Hayoz S, Bernhard J, Zwahlen DR, Hölscher T, Gut P, Guckenberger $\mathrm{M}$, et al. Acute toxicity and quality of life after dose-intensified salvage radiation therapy for biochemically recurrent prostate cancer after prostatectomy: First results of the randomized trial SAKK 09/10. J Clin Oncol. 2015;33: 4158-66.

25. Goldin GH, Sheets NC, Meyer AM, Kuo TM, Wu Y, Stürmer T, et al. Comparative effectiveness of intensity-modulated radiotherapy and conventional conformal radiotherapy in the treatment of prostate cancer after radical prostatectomy. JAMA Intern Med. 2013; 173:1136-43.

26. Christodouleas JP, Hall MD, van der Pas M, Guo W, Schultheiss TE, Gabriel P. Changing patterns of care for locally advanced non-small cell lung cancer: Implications for quality initiatives. Int J Radiat Oncol Biol Phys. 2015;93:S120.

27. Bradley JD, Paulus R, Komaki R, Masters G, Blumenschein G, Schild $\mathrm{S}$, et al. Standard-dose versus high-dose conformal radiotherapy with concurrent and consolidation carboplatin plus paclitaxel with or without cetuximab for patients with stage IIIA or IIIB non-small-cell lung cancer (RTOG 0617): a randomized, two-by-two factorial phase 3 study. Lancet Oncol. 2015;16: 187-99.

28. Boffa DJ, Rosen JE, Mallin K, Loomis A, Gay G, Palis B, et al. Using the National Cancer Database for outcomes research: a review. JAMA Oncol. 2017;3:1722-8. 